\title{
Community Institutional Arrangements for Conservation and Development Through Tourism: An Analysis of the Nkuringo Conservation and Community Development Foundation, Uganda
}

\author{
Jockey Baker Nyakaana, Wilber Manyisa Ahebwa, Waliya Gwokyalya \\ Makerere University, Kampala, Uganda
}

\begin{abstract}
Tropical forests provide some of the richest biodiversity amid and adjacent to the world's poorest people as they lose access to resources when forests are designated for strict preservation. Integrated Conservation Development Projects (ICDPs) aimed at conservation and compensated communities adjacent to conserved resources through revenue sharing from the resultant economic activities. However, Community-Based Natural Resource Management (CBNRM) approaches seek to reconcile biodiversity conservation with community livelihoods strategies to reduce poverty. Nkuringo Conservation and Community Development Foundation on the Southern Fringes of Bwindi National Park in Kisoro District adopted the Community-Based Natural Resource Management model where communities benefit both financially and socially from conservation. The model provides a "win-win" situation where both human beings and wildlife benefit. The objective of this paper is to profile Nkuringo Conservation and Community Development Foundation (NCCDF) adoption of the model by analyzing the model, actors involved, the legal framework, benefits accrued, challenges, and strategies to ameliorate them. The paper adopted a case study research design and collected both qualitative and quantitative data using desk top research methods, observation, oral interviews, and focus group discussions (FGDs). The communities of Nteko and Rubuguri parishes participate in the project which has conserved the mountain gorillas and forests for tourism and diversified community livelihood through tourism, sale of handcrafts, an eco-lodge (Clouds Lodge) and commercial agriculture which contribute to poverty reduction.
\end{abstract}

Keywords: community, conservation, culture, legal frame work, sustainable development

\section{Introduction}

Tropical forests world over provide some of the richest biodiversity amid and adjacent to the world's poorest people who pay the cost of conservation as they lose access to resources when forests are designated for strict conservation (Adams et al., 2004). Livelihood related threats that catalyze negative attitudes and illegal activities in protected areas have been advanced as major reasons for the failure of the "fortress"/"strict" conservation philosophy (Coad, Campbell, Miles, \& Humpries, 2008; Saito, 2007; Hecker, 2005). Subsequently,

Jockey Baker Nyakaana, Ph.D., professor, Department of Forestry Biodiversity and Tourism, Makerere University, Kampala, Uganda.

Wilber Manyisa Ahebwa, Ph.D., associate professor, Department of Forestry, Biodiversity and Tourism, Makerere University, Kampala, Uganda.

Waliya Gwokyalya, Ms. LLM, lecturer, Makerere University Business School, Makerere University, Kampala, Uganda. 
conservation approaches in Africa and other developing countries have embraced the principles: (i) that conservation should be community-based; (ii) that conservation should be sustainably managed to achieve community development; and (iii) that markets should play a role in shaping incentives for conservation (Ahebwa, 2012; Hulme \& Murphree, 2001). The third principle largely reflects the neo-liberalism rhetoric that seeks to commodify nature and develop market-based mechanisms for its conservation (Büscher, 2008). This has been scaled down to Africa by international conservation and development organizations through national governments. Nature-based tourism is one of the most widely applied mechanisms to achieve conservation and development and a means to embrace the above three principles (Tao \& Wall, 2009; Ashley, 2000; Ross \& Wall, 1999; Ashley \& Roe, 1998). Advocates of this approach suggest it can provide "win-win" outcomes for conservation and development by generating tangible benefits that compensate for costs and create incentives for nature conservation and poverty alleviation (Wells \& MacShane, 2004; Font, Cochrane, \& Tapper, 2004; Goodwin, 2002). The development of nature-based tourism is highly regarded as one of the possible solutions to poverty in the developing countries and is recognised by United Nations (UN) as one of the major tools to achieve the Millennium Development Goals (MDGs): (1) "ending poverty and hunger" and (2) "environmental sustainability" (United Nations World Tourism Organization [UN WTO], 2008).

Attempts have been made to reconcile the management of protected areas with the social and economic needs of the communities through various tourism hinged programs or approaches. The initial attempts to achieve this were popularly known as Integrated Conservation Development Projects (ICDPs) (Wells, Brandon, \& Hannah, 1992; Wells \& Brandon, 1993; Nthiga, 2014). Through ICDPs, the affected communities have been compensated through financial rewards and socio-economic projects funded with income from the non-consumptive economic activities developed in the protected areas. In Uganda, this approach has been relatively successful as the communities have benefited through income gains and improved access to social services (Ahebwa, van der Duim, \& Sandbrook, 2011; Nyakaana \& Ahebwa, 2011; Wells et al., 1992), but in many areas, the linkage between development and conservation is either missing or obscure as communities around many protected areas (PAs) are still passive beneficiaries and not active collaborators (Barrow, Gichohi, \& Infield, 2000; International Gorilla Conservation Programme [IGCP], 2011).

As a beef up, Uganda embraces other Community-Based Natural Resource Management (CBNRM) approaches that seek to reconcile biodiversity conservation with local livelihoods to avoid worsening the situation of the poor communities living within and around the protected areas (Muramira \& Sikoyo, 2001; IGCP, 2011). The ingredients of the CBNRM model seek to achieve a "win-win" situation where both communities and wildlife benefit. Although there is no doubt that these approaches have generated considerable benefits, concerns have been raised about the inequitable distribution of benefits and power among different actors and at different scales, insignificant economic impacts at community level, undermining the effectiveness of these approaches as tools for conservation and development (Wells et al., 1992; Goodwin, 2002; Kiss, 2004; Dabrowski, 2007; Brockington, Duffy, \& Igoe, 2008; Sandbrook, 2008; Sachedina, Igoe, \& Brockington, 2010; Laudati, 2010). Various strategies have emerged with claims that they can circumvent or address such concerns (Ahebwa, 2012). The strategies are: (i) direct community involvement in tourism enterprises (Mburu, 2003; Ashley \& Ntshona, 2003); (ii) protected areas outreach arrangements (Archabald \& Naughton-Treves, 2001; Saarinen, Becker, Wilson, \& Manwa, 2009); (iii) public-private partnerships (Varghese, 2008; Spencely, 2003); (iv) private-community partnerships (Southgate, 2006); (v) public-community initiatives (Mburu, 2003); and (vi) public-private-community partnerships (Spencely, 2003; 
Ashley \& Roe, 1998). There is however need to understand and examine the institutional arrangements within which these strategies are implemented as they impact on conservation and development. This paper addresses this by looking at the Nkuringo Conservation and Community Development Foundation (NCCDF) - a community entity in the Southern Sector of Bwindi Impenetrable Forest National Park, Uganda that has engaged Strategy (iv) for conservation and development. The study set out to assess the institution of NCCDF, stakeholders, the legal and policy frame work under which it operates, its successes, challenges, and proposals to enhance the successes and ameliorate the challenges.

\section{Methodology}

The research for this paper was conducted in Nteko and Rubuguri parishes in Kisoro District where NCCDF is housed. The two parishes board Bwindi National Park to the South. The study adopted a case study research design. Data were collected through observation of the conservation and socio-economic activities the communities are involved in. Through oral interviews with NCCDF administrator, manager of Clouds Mountain Gorilla Lodge, community leaders, tourism officer in Kisoro District, and manager IGCP, both quantitative and qualitative data regarding NCCDF activities, legal and policy framework, successes, and challenges were obtained through documentary review and interviews. Through two focus groups discussions with communities in Nteko and Rubuguri, qualitative data on their participation, benefits, and challenges associated with NCCDF were obtained.

\section{Study Area}

The study was conducted in Nteko and Rubuguri parishes in the sub-counties of Nyabwishenya and Kirundo respectively in Kisoro District (see Figure 1) where NCCDF operates. The parishes have a total population of 34,876 of whom 15,000 are adults and therefore members of NCCDF.

\section{CBNRM Model}

CBNRM model focuses on collective use and conservation of natural resources (biodiversity) by a group of people with a self well defined identity which affect and are affected by conservation decisions in planning and stewardship using commonly owned facilities as to provide direct economic and social benefits while sustaining biodiversity (Fernandez-Gimenez, 2008; Fabricius, 2007; Danida, 2007) (see Figure 2).

It has triple objective of poverty reduction, natural resource conservation, and good governance which unfortunately are not mutually supportive (Danida, 2007) (see Figure 3). It does not only focus on sustainable management of natural resources but also community development, self-governance, and creation of community institutions for the sustainable management of these resources. Though financial benefits are important, most important are the non-financial benefits which include but not limited to empowerment of the communities, conservation of the biodiversity, and development of several livelihood strategies and reduction of risks (Fernandez-Gimenez, 2008; Fabricus, 2007). 


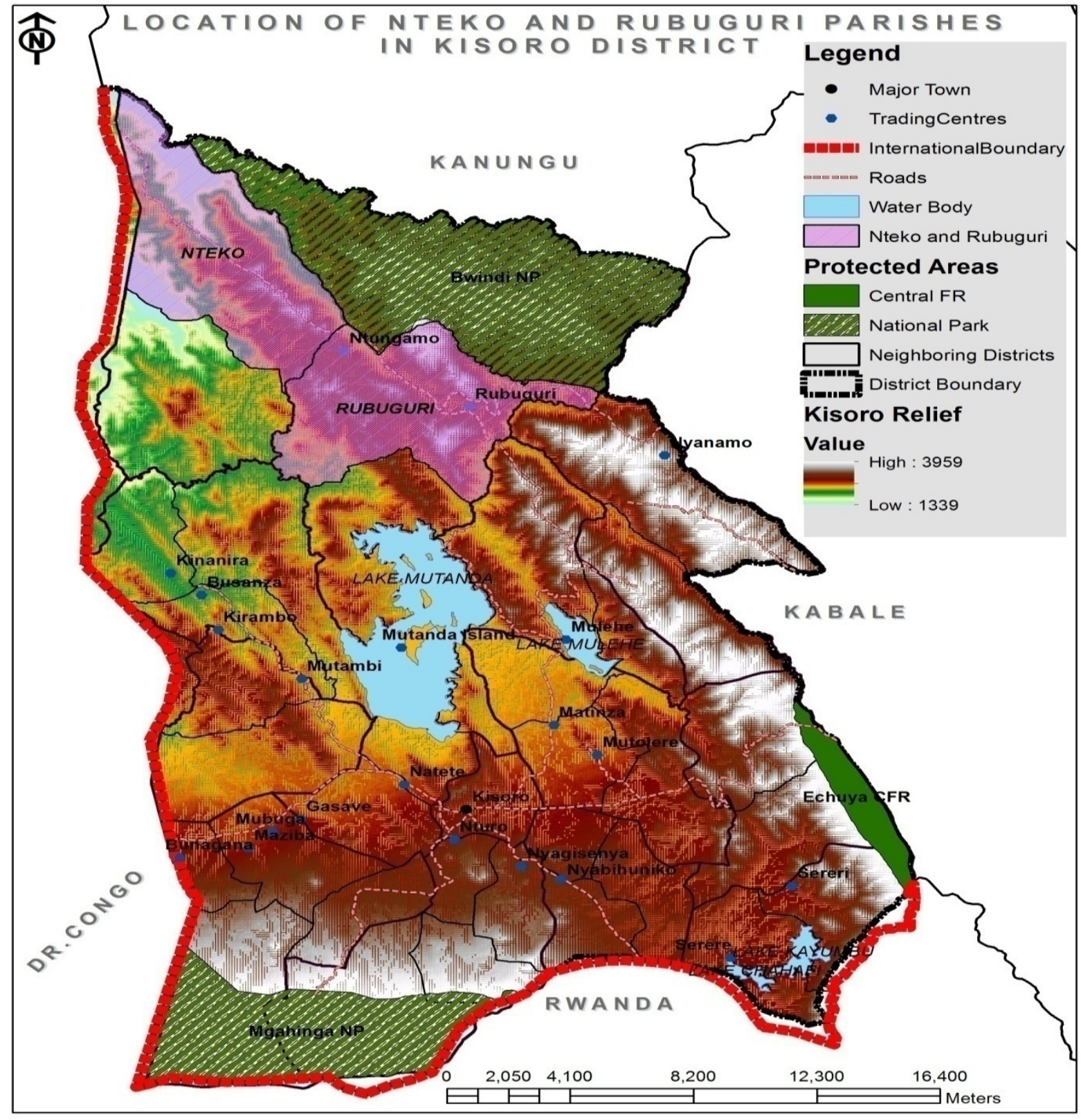

Figure 1. Kisoro District map. 


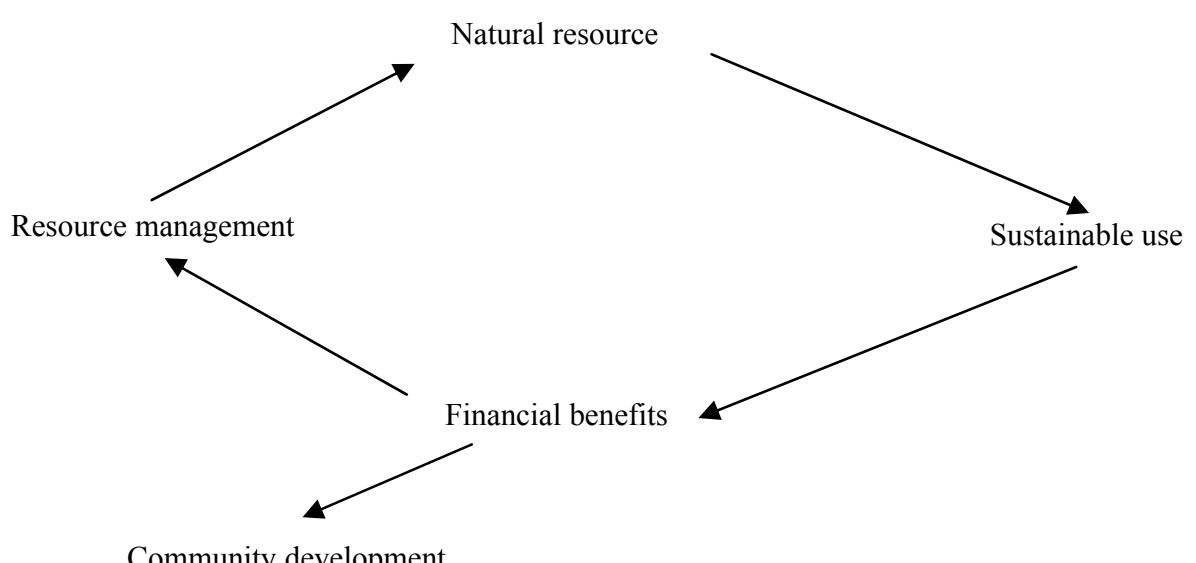

Figure 2. Community-Based Natural Resource Management model (Source: Danida, 2007).

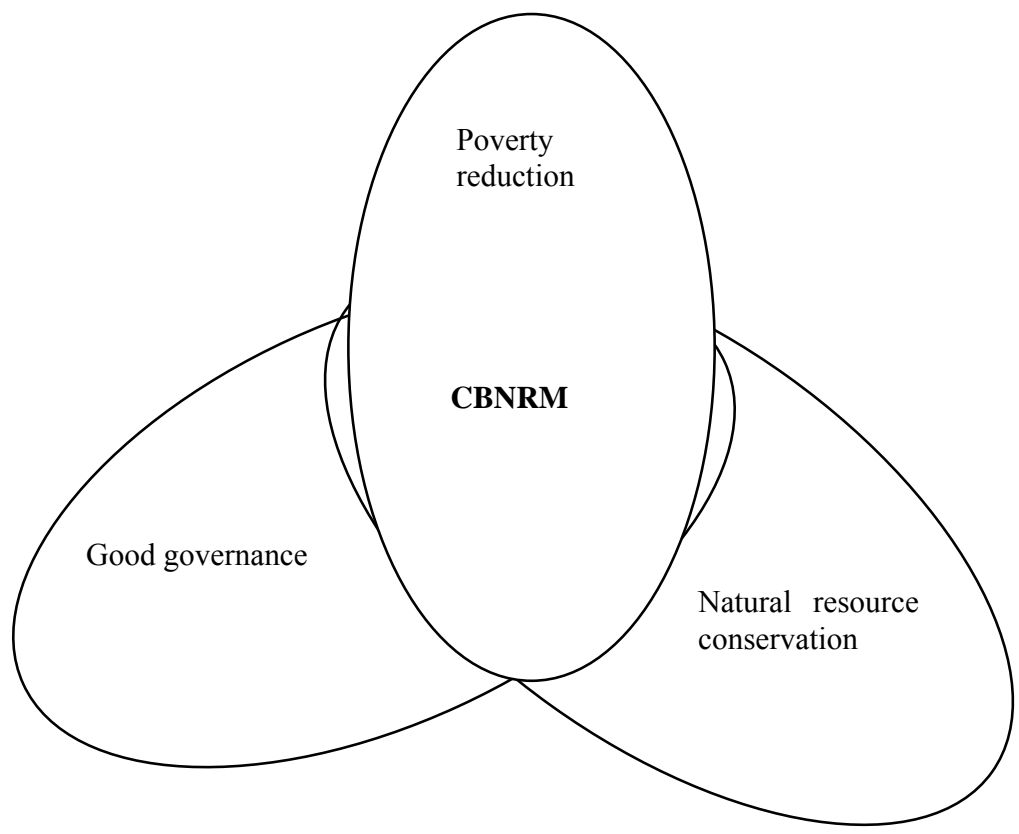

Figure 3. Objectives of CBNRM (Source: Danida, 2007).

Successful implementation of CBNRM requires changes at national level through policies and legal framework to establish an enabling environment to make CBNRM attractive to local communities. At the intermediate level, there is need for decentralization of natural resource management authority to elected local governments, line agencies, and authorizing district to delegate management authority to local communities (Fabricus, 2007; Danida, 2007; Igoe, 2006) (see Figure 4). At local level, CBNRM should create economic incentives for managing and conserving the resources where community members experience net gains. 


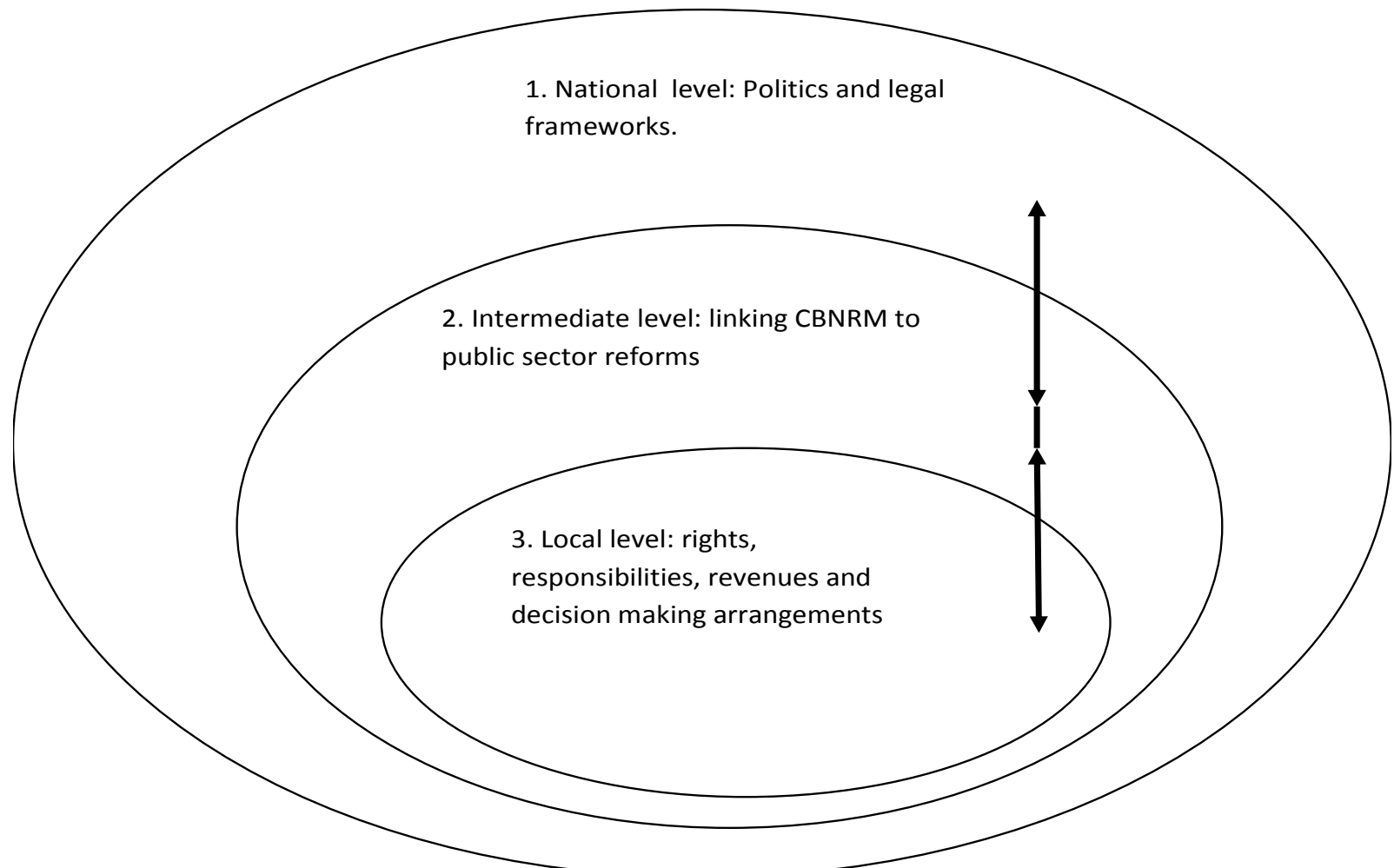

Figure 4. Requirements for the successful implementation of CBNRM (Source: Danida, 2007).

\section{Results and Discussion}

\section{The Institution of NCCDF and the Adoption of the CBNRM Model}

NCCDF was registered in 2004 as a company limited by guarantee and owned by the communities where all adults born and living in Nteko and Rubuguri parishes in the sub-counties of Nyabwishenya and Kirundo respectively in Kisoro District (see Figure 1) are members. It is headed by an administrator who works under a board of 50 directors who serve for four years and is elected during an Annual General Meeting (AGM). The foundation activities include handicraft making, nature walks, Batwa culture, traditional music, dance and drama, bird watching, community camp sites, nature conservation, and owning Clouds Mountain Gorilla Lodge in partnership with Uganda Safari Company.

The foundation was registered after the IGCP had purchased land from the communities to create a buffer zone of 300 meters wide 12 kilometers long to prevent animals from the park crossing into people's gardens. It was responsible for sensitizing communities on conservation and financial management, fundraising, leadership identification, monitoring, and evaluation of community activities. The buffer zone had been planted with different commercial plants (lemon grass and Artemisia) which unfortunately did not yield the expected financial returns. In 2012/2013, tea was introduced and community groups (Engozi-stretcher groups) were allowed to plant six to seven acres each. Government provided tea seedlings and National Agriculture Advisory Services (NAADS) sensitized the people on tea growing. 
NCCDF resources are Bwindi National Park, culture, Buniga and Kafuga forests, and the buffer zone. These resources can be sustainably used through tourism (gorilla tracking, bird watching, nature walks, cultural activities, homestead tourism, handicrafts, campsites, and accommodation facilities). The success of tourism depends on provision of attractions and facilities of international standard. In this regard, NCCDF members contributed Shs. 1,000 each and purchased land. Using donor funds from United States Agency for International Development (USAID) through IGCP, the community constructed Clouds Mountain Gorilla Lodge which was leased for 15 years (2008-2023) to Uganda Safari Company. The lodge charges between $\$ 600$ and $\$ 1,000$ full board per night per person and NCCDF is paid $\$ 40$ per bed night (NCCDF \& Uganda Safari Co. Contract 2008).

The bed nights increased from 445 in 2008 to 1,117 in 2015 with the highest record of 1,542 in 2014. The lodge employs 12 out its 14 staff from the community who earn between Shs. 100,000 and Shs. 300,000 per month and their level for education is between S4 and S6. Staff members can sell their farm produce to the lodge and tourists buy handicrafts from the community. Other financial benefits to the community from tourism are the payments made to tour guides, the Batwa (minority group) when they perform (music, dance, and drama) for the tourists. Each tourist pays $\$ 25$ of which $40 \%$ goes to NCCDF, $60 \%$ to the 10 dancers. If there is only one tourist, the $\$ 25$ goes to the dancers. Tourists can visit the Batwa settlement to have a real experience of their life style and the proceeds go directly to the hosts just like payments from the purchase of handicrafts. However, tour operators are not enthusiastic about the visit to the Batwa homes as they are the ones to pay from the tour package costs.

The group tea project introduced in the buffer zone in 2012/2013 did not succeed as there was no tea factory in the neighborhood and the government contracted Kigezi Highlands Tea Company (KHTC) as the lead agency to develop tea in Kisoro District. The company took over the growing of tea in the buffer zone and laborers were paid Shs. 5,000 and free lunch to work from 9:00 a.m. to 3:00 p.m. Unfortunately, NCCDF does not know the terms and conditions agreed upon between KHTC and government and yet tea is being grown on their land, harvested, and taken by the tea company. There is no operational legal contract between NCCDF and KHTC regarding these activities which pauses a threat to the community in terms of returns from tea for their economic development.

Between 2014 and early 2016, many people including children benefited as laborers in the tea plantation. During a FGD in Nteko, a primary two girl said:

Tea helped us as a family. We had free lunch and the money earned was useful. My goat now has a kid and my mother bought us clothes and household utensils. However, our father just spent his money on alcohol.

A female participant in Rubuguri said:

Tea has helped the village to develop and we want it revamped for we are now suffering from poverty as KHTC has suspended its activities.

A builder in Rubuguri said:

My wife did not work in the tea plantation; she tended our gardens of food crops. However, those working there give me work to construct their houses. I benefit a lot from tea growing as I earn between Shs. 100,000 and Shs. 250,000 per month as a mansion. Suspension of tea growing by KHTC has affected everyone in the village. We need tea like a gorilla needs a forest. 
However, tea growing outside the buffer zone is degrading the environment especially Buniga forest owned by the National Agricultural Research Organisation (NARO) but shared between NARO 20\% research, NCCDF $20 \%$ conservation, and KHTC $60 \%$ tea growing. NCCDF has applied to the district authorities to be granted permission to conserve Kafuga forest but the politicians want it for tea growing arguing that tea shall contribute more to poverty reduction than conservation. Unfortunately, tea growing as a consumptive use of resources is less sustainable as compared to tourism which NCCDF plan to introduce. During a FGD in Rubuguri, one elder said:

We praise tea as providing income but look at the destruction inflicted on Buniga forest. Compare where tea is grown and where the tourists go for walks. Which of the two is better? The tea money has now stopped but tourists are still coming and those involved are still earning. We need tourism more than tea if our grandchildren are to benefit from these forests.

An elderly lady in Nteko said:

Both tourism and tea growing are good. However, tea is for today while tourism is for today, tomorrow and for posterity as the former destroys the forests while the latter protects them. If tea had been here since independence there would be no forests in the district. Where would we be without the forests? Remember forests bring rain for our crops.

\section{Policy and Regulatory Framework Within Which NCCDF Operates}

NCCDF activities are guided by different policies and laws. Before 2000, community involvement in conservation of wild life was done through specific activities in the national parks, donor and non-governmental organization (NGO) funded projects through community institutions, and training community in conservation skills. The Constitution of the Republic of Uganda of 1995 objective X111 obligated the government to protect natural resources including land, water, wetlands, minerals, oil, fauna, and flora on behalf of the people of Uganda. It did not include the involvement of the local community in the management of the conservation areas but laid a platform for the development of other laws and policies requiring the participation of communities in the conservation of wildlife in protected areas to enable them benefit socially and economically (Barrow et al., 2000). This came to the fore when formulating the Local Government Act of 1997 (Cap 243) which allows community participation in matters on conservation of wildlife in their areas of jurisdiction.

The Wild Life Act 2000 sought to promote the sustainable management of wild life resources, the conservation of selected species of wild life, public participation at all levels, and enhancement of economic and social benefits to the communities among others. This was a win-win situation as both community and wildlife would benefit. The community would be involved through establishment of local government wildlife committees to advise Uganda Wildlife Authority (UWA) on the management and utilization of wildlife with in their jurisdiction. This provided an avenue for the community to engage in the management of wildlife in their areas while at the same time negotiating for a share in the benefits of tourism. This created a sense of belonging and appreciation for the need to conserve natural resources (Uganda, 2000, 2008; NEABS, 2005).

However, the question is whether these local committees are actually in place and their voice is heard by UWA and actively taken on in decision making or whether it remains on paper. Communities neighboring wildlife protected areas through UWA are given usufructuary rights of access to resources which are crucial to their survival (Sec. 25(2)). This creates positivity among the communities and motivates them to conserve natural resources for tourism while at the same time enhancing their livelihood. On payment of a user fee to 
UWA, the act grants commercial wildlife user rights to a person or community for farming, hunting, ranching, trading in wildlife and its products, educational or scientific purposes and general extraction (Uganda, 2000). However, this does not put into consideration the community who cannot afford to pay yet have for years benefited freely from the protected areas before the conservation efforts. Ordinarily, the livelihoods of the communities of Nteko and Rubuguri, especially the Batwa, were dependent on the forests for meat, medicine, honey, fire wood, and settlement. Requirement to pay fees for enjoyment of such rights totally incapacitates them from enjoying any more benefits from such resources.

The Uganda Wild Life Policy 2014 was promulgated in line with the Wildlife Act to provide an overall policy for the conservation and development of wildlife resources of Uganda. It provides a framework within which all stakeholders in the wildlife conservation industry (government institutions, private sector, civil society, and development partners) should operate in the conservation of wildlife resources. It emphasizes government commitment in involving communities in the conservation of wild life resources as well as ensuring that the community benefits from conservation. The policy compounds all laws on the conservation of natural resources as it aimed at mitigating human wildlife conflicts and enhancing a positive attitude amongst the community and local authorities towards the conservation and management of wildlife; policy-makers at all levels enhance the sustainable utilization of natural resources in bid to improve the livelihood of the populace and reduce poverty. This was to be achieved through promotion of such areas as a focus of community involvement, pride, ownership, commitment, source of socio-economic benefits, and promotion of community conservation through alternative livelihood improvement projects (Uganda, 2014).

In the case of NCCDF, though the strategies geared to the implementation of the policy have largely remained on paper, some benefits have been attained as alluded to in the next section of this paper.

Uganda is a signatory to several regional and international instruments on natural resource conservation, such as: The East African Community Protocol on Environment and Natural Resources Management 2006, Convention on Biological Diversity of 1992, Convention on Migratory Species of 1979, and Convention on International Trade in Endangered Species of Wild Fauna and Flora of 1973, and is obligated to honor them. The East African Protocol on Environment and Natural Resources Management which Uganda ratified in 2010 obligates Uganda to sustainably conserve wildlife resources in conjunction with the communities. In bid to benefit from tourism, NCCDF as owners of Clouds Mountain Gorilla Lodge, entered into a renewable agreement with the Uganda Safari Company (TUSC) Ltd. in 2008 to operate the lodge as an eco-lodge for 15 years. The contract was drafted by the Uganda Safari Company Ltd. through their agent; Kaplan \& Stratton in Kenya. Although NCCDF Ltd. duly executed the agreement, it bore some loop holes which would later negatively impact on the social-economic development of the community. The lodge is obligated to pay an annual rent of $\$ 5,000$ net of all taxes with an annual increment of $5 \%$. This increment is unrealistic compared to the increase of guests at the lodge from 445 in 2008 to 1,117 in 2015. The lodge in essence benefits more from the growing business while the benefits to the community do not increase at a similar pace. The lodge also pays NCCDF bed night fees of US $\$ 40$ per guest net of taxes with an annual increase of $5 \%$. This is again unrealistic compared to the charge of US\$600 to US $\$ 1,500$ per guest per night full board. However, bed night fees remitted by the lodge have never been revised since the inception of the contract and are not paid on time which affects NCCDF in execution of its plans.

In the contract, Clouds Lodge was appointed as the sole private investor in the lodge business in the Nkuringo region which deters competition as it locks out potential investors from participating in this lucrative 
business. The community looks up to the lodge for benefits which include but not limited to employment opportunities, market for agricultural produce, revenue for infrastructural development and increasing the capital base for the NCCDF fund from where members can borrow for their personal development which delimits the development of the community. As sole operator, continued stay in the business is guaranteed and the lodge is more interested in making profits than working out ways of giving back to the community to enhance its socio-economic development.

The contract confers a right on the operators of the lodge to renew their lease for another 10 years on similar terms as the previous lease except for bed night fees and rent. Although NCCDF agreed to these terms by assenting to the agreement, this proviso is unfair considering the loopholes in its present form specifically regarding the clause giving Clouds Lodge the power to operate as sole developer in the lodging business in the area. Renewal of the lease with such a term continues to incapacitate NCCDF in terms of infrastructural development of the area since it stifles competition together with the associated benefits.

\section{Successes and Strategies to Enhance Them}

NCCDF has achieved successes for the community and individuals. The people who sold their land for the buffer zone got money which some used to buy bigger pieces of land and are now better off than before. However, those who got the money and spent it on alcohol are living in misery.

Sensitization on financial management conducted by IGCP during the early stages of NCCDF benefited the communities who have now set up saving and Credit Co-operative Societies (SACCO) to save their money which they later borrow for individual development. A participant had this to say:

When we harvested timber we used to drink the money now with park levy we have benefited greatly. We have been taught how to save and from the savings, we pay school fees and build better houses. The women buy better clothes, household needs, goats, pigs all of which contribute to family welfare. We are better off today than before the coming of NCCDF.

The increase in disposable income among the community members has attracted entrepreneurs to set up a diversity of businesses especially retail shops and grinding mills which not only create employment but development of the parishes.

The establishment of NCCDF and the associated tourism activities and tea growing have created diverse employment opportunities for both children and adults. Clouds Lodge employs 12 of its 14 workers from the communities. Other youth from the community are trained in hotel related activities and deployed to other accommodation facilities owned by Uganda Safari Company. However, this source of employment is still low and takes those with S4-S6 education and the pay is low (Shs. 100,000-300,000 per month). NCCDF employs only members of the community; the Batwa who were resettled from the forest have been trained in handicraft making which are sold to tourists, so are the other members of the community especially the women. The Batwa also work as tour guides and traditional dancers which earn them income. Though living a settled life, the Batwa are still poor. The major source of employment is in tea growing activities which employ both children and adults at a rate of Shs. 5,000 per working day from 9:00 a.m. to 3:00 p.m. During the FGDs, most people were praising tea growing for creating employment and reducing household poverty. A 12-year-old girl in primary school said:

During the holidays I work at the tea plantation and the money contributes to our household upkeep, bought two piglets which are about to deliver. That is more money for the family. Tea growing is a blessed source of income for us. 
An elder said:

Tea has brought prosperity to the community. It creates employment to all of us. The lead agency should be paid so that we get employed.

A lady in her mid fifties said:

Tea is gold to us just as tourists are to Cloud lodge: Tea growing should be revamped to avoid the communities deteriorating to the days of 1980 s.

Despite the conservation efforts and the associated economic activities, sustainable employment opportunities are still limited, and the income obtained is not substantive as to reduce poverty levels in the community.

Cloud Lodge and NCCDF management undertake fundraising activities from tourists and this has helped to raise funds for the weavers groups, five primary schools, and two secondary schools and scholarships for nurses and some orphans.

Table 1

Livelihood Implications of the NCCDF's Clouds Lodge Venture

\begin{tabular}{|l|l|}
\hline Livelihood aspect & Implications \\
\hline Assets and outcomes & \\
\hline Financial capital & $\begin{array}{l}\text {-Both direct and indirect employment. } \\
\text {-To some extent market for local produce, e.g., Irish potatoes, firewood, charcoal, beans, eggs } \\
\text { and crafts have been created. } \\
\text {-Pigs and cattle projects for some community members. }\end{array}$ \\
\hline Social capital & -Water supply to the communities, conflicts. \\
\hline Human capital & $\begin{array}{l}\text {-On job training for the lodge employees. } \\
\text {-Scholarships to best students from the community. }\end{array}$ \\
\hline Physical capital & $\begin{array}{l}\text {-Community Lodge. } \\
\text {-Community Land where the lodge is built. }\end{array}$ \\
\hline Natural capitals & \\
\hline
\end{tabular}

Financially, the eco-lodge currently employs a total of 48 people directly as waiters, cleaners, cooks, drivers, bar attendants, supervisors, and managers. Of these, 94\% (45) of the employees are from Nteko and Rubuguri parishes (members of NCCDF) and only three are hired from outside the two parishes as the Lodge manager clarified:

There are 3 technical positions (Manager, Chefs) where outsiders were hired as NCCDF never had skilled people to efficiently serve in those positions. We always give preference to members of NCCDF when it comes to job allocation...in fact look at all these boys and girls... They are from the community.... We train them and they are doing a good job. We expect them to in turn help their families....

Those employed sounded very happy with their new positions and admitted receiving on job training as well as "good" monthly pay which they argue has assisted their families. On what they do with the money, they listed paying school fees for their children, brothers and sisters, meeting medical bills and building iron roofed houses:

We had never thought of this opportunity in a remote village like ours... The management is so good, we were thoroughly trained and we are paid on time thanks to IGCP, UWA and TUSC. The money we earn has gone a long way in addressing our school fees, medical, and housing needs and we hope for the best.... 
In the three years of operation, the Lodge spent UGX 22,039,500 (approx. US\$10,017) on casual laborers who do part-time jobs (African Wildlife Fund [AWF], 2010). Other people have been employed indirectly as guides (10), craft makers as well as administrators of NCCDF.

However, focus group discussions (FGDs) revealed complaints from some NCCDF members that some of their children are only employed for a short time and then are chased. Most of these members in principle were happy with the Lodge arrangement, but were only bitter with the Lodge Administration. They argued that within the NCCDF-TUSC agreement, a procedure to terminate some one's contract was clear, such an individual should be called in a disciplinary committee comprised of some NCCDF members and Clouds Lodge management. Then, they would be given a fair hearing before a decision to terminate their contracts was implemented. However, the management is accused of bypassing this clause. One former employee argued as follows:

I was employed as a driver at Clouds Lodge.... My job was to pick clients from the airfield in Kisoro and drop them back at the end of their visit. One day, the manager told me to pack and go.... I was shocked.... These days, he drives the visitors himself. He has also employed his girlfriend. Yet this is our Lodge. We complained, but the Chairman NCCDF is also powerless.

On the contrary, the Lodge Manager argues that people whose contracts are terminated are incompetent:

It is true, some employees' contracts are terminated if they become incompetent.... The problem is that the community here has high expectations. But true this hotel is theirs; we have to manage it effectively. For those employees who serve well, we have them.

This scenario pointed to failure to stick to the rules of the game by actors especially TUSC. But this also may be a result of the complexities of working with a tribal community. While a private sector actor may be interested in competence and prudent service provision, the local actors may be interested in protecting tribal identities which automatically creates clashes of perspectives.

On local sourcing of materials, TUSC has to some extent fulfilled its obligation as most building materials that were available in communities were sourced locally and food stuffs available locally, like eggs, chicken, vegetables, and potatoes, are bought. For example, over the last three years in operation, TUSC has spent UGX $37,045,600$ (approx. US $\$ 16,838$ ) on local market purchases, UGX 3,261,900 on firewood, UGX 1,352,650 on water, and UGX 2,127,300 on crafts from the community (AWF, 2010). This local sourcing implies that finances are injected into a community that was so remote relying on agriculture and without accessing market for the produce.

In the focus group discussions especially in Nteko, the community members admit that some benefits are trickling down and appreciate the role of the Lodge in diversifying their incomes. However, the atmosphere was different in Rubuguri as they seemed not to know about all these opportunities created by the lodge. One reason could be that the Lodge is located in Nteko and therefore communities there can easily access these opportunities. The Lodge Manager indicated that the venture could have contributed more benefits to the community through purchase of foodstuffs but because of limited and inconsistent supply, management is at times forced to shop from Kabale town and other areas. Despite this, the Rubuguri pressure group argues that the Clouds Lodge management buys everything from Kabale even when it is locally available. But a talk with residents of Nteko, threw weight behind the Clouds Lodge Manager's argument. In the short period of the lodge operation, it was revealed that some pig and cattle projects have been facilitated and water supply arrangements started in the parishes of Nteko and Rubuguri. 


\section{Challenges and Strategies to Reduce Them}

NCCDF like any other institution in Uganda faces various challenges and the most notable is inadequate income from the established economic activities. Income from tourism is inadequate as tourist numbers are low and fluctuate depending on the prevailing conditions in the country. The remittances from the lodge are low and not paid on time which affects their operations. Bed night fees remitted to NCCDF should be in percentage form of at least $25 \%$ per bed night instead of the fixed $\$ 40$. This will enable the community get an increased yield from this thriving business and reward their conservation efforts.

There are policy weaknesses at national and local government level as tourism is at times given lip service and policies (for instance, those on environmental conservation) are neither implemented nor monitored. Although there are several legislations promoting private sector participation in the conservation of natural resources, such as: The Uganda Wildlife Policy, 2014 and The Wildlife Act (Cap 200), there is no specific legal framework regulating the operation of private enterprises in conservation areas. Many investors contract with the community which is not fully informed of their rights and considering the remoteness of the conservation areas, their negotiating power is limited.

Government should formulate specific policies to regulate private sector investment in the natural resource conservation areas. Considering that such businesses benefit substantially from the tourism business, the policy should assert preconditions requiring investors to physically contribute to infrastructural development of their areas of operation in definitive models and time.

NCCDF has no knowledge on how tea growing was granted to KHTC which took over tea growing in the buffer zone which is their land and is now demanding payment from NCCDF for the tea growing activities and yet it takes the tea leaf for processing and sell. At the time of research KHTC tea plantations were in a bush as KHTC claimed government had not paid them, so they suspended tea growing activities in the area. This questions the sustainability of tea growing by KHTC as the lead agency and the policy and legal framework of its establishment which threatens the sustainability of NCCDF and failure to reduce on poverty. It has increased the rate of school drop outs, promiscuity, prostitution, and food insecurity all of which are a threat to sustainable development. During a FGD, an elder said:

Tea growing has caused problems, people no longer attend to their gardens. We have to buy maize flour and it is expensive, children cannot study as they have money to buy radios and clothes, others are in prostitution.

The Batwa who were withdrawn from the forest where they lived a nomadic life dependent on nature and forced to undertake agriculture on a small piece of land are a threat to the sustainability of NCCDF. A Batwa elder said:

My life is not good because we don't have land and that we are accommodated by other people. We don't live with them on good terms. They often tell us to destroy our houses and leave their land. We ask the government to help us. Our people have no peace.

And another one said:

Life outside the forest is better but challenging as we are made to live outside our culture. We sympathize with our children and grandchildren who have lost our culture and could easily disappear from earth as a tribe.

The contract agreement signed between NCCDF and the Uganda Safari Company (TUSC) as the sole lodge operator in the area stifles NCCDF development. There is dire need to open the market for competition as 
this will increase employment opportunities for the community, market for agricultural produce, motivation to engage more in agriculture to meet the market demand. Lodges would also strive to give back to the community in terms of infrastructural development and employment, in an attempt to build their image and remain relevant in the community. Opening the space for competition will increase income for NCCDF and investors would strive to give better rates to the community so as to remain in business.

\section{Conclusions}

The institution of NCCDF guided by its regulatory framework is making good progress regarding creating the crucial linkage between communities and tourism through natural resource conservation. The tourism and non-tourism related ventures initiated by NCCDF have gone a long way in addressing the livelihood needs of the community, creating jobs, markets for community products, and financing some community projects. The rotational election of leadership of NCCDF by members of beneficiary communities (Nteko and Rubuguri parishes) has enabled a strong institutional framework, sustainable in its nature of operation. With the lucrative gorilla tourism in the Southern Sector of Bwindi, the benefits to the community are likely to increase. The strategic partnership with private sector has given NCCDF an opportunity to benefit from business expertise, networks, and experience of the private operators to attract business and tourism money to this once remote part of the country.

The story to relative progress, however, is not without challenges and constraints. First, the income and jobs generated through NCCDF ventures compared to the large poor populations in this area pose a big challenge. This may necessitate mainstreaming tourism benefits with other government initiated development projects to be able to cause a visible impact on poverty alleviation. Other challenges relate to governance, corruption, and inadequate community sensitization that is common with community-based organization.

\section{Recommendations}

The community should be sensitized on the big picture of conservation costs and benefits, poverty reduction, and sustainable development. They should be trained on modern farming methods as to ensure sustainable food supplies. CBNRM should be made part of a broader multi faceted national strategy to deal with poverty and should be strengthened through further policy reform and improved implementation.

The government should promulgate conservation laws where the roles and relationship between the stakeholders are clearly defined. The government at all levels should ensure that conservation adheres to the laid down policies and procedures where communities benefit after losing access to use the conserved resources. The contract between TUSC and NCCDF should be revisited with an aim to increase the fees to NCCDF for instance bed night should be $25 \%$ of the bed night charges. The contract between government and KHTC should be availed to NCCDF and should be made favorable to NCCDF.

NCCDF should be given conservation rights of all the natural resources in Nteko and Rubuguri. The available labor laws should be implemented and children prevented from working on the tea plantations.

Communication network within/outside the parishes should be improved so that the tourists access the place more easily.

\section{References}

Adams, W. M., Aveling, R., Brockington, D., Dickson, B., Elliot, J., Hutton, J., ... Wolmer, W. (2004). Biodiversity conservation and the eradication of poverty. Science, 306(5699), 1146-1149. 
African Wildlife Foundation. (2001). The impact of wildlife-based enterprises on local livelihoods and conservation in Uganda. Wildlife Enterprise for Local Development (WELD). Retrieved from https://www.awf.org/old_files/documents/WELD-Uganda.pdf

Ahebwa, M. W., van der Duim, V. R., \& Sandbrook, C. G. (2011). Tourism revenue sharing policy at Bwindi Impenetrable National Park, Uganda: A policy arrangements approach (PAA). Journal of Sustainable Tourism, 20(3), 377-394.

Ahebwa, W. M. (2012). Tourism, livelihoods and biodiversity conservation: An assessment of tourism related policy interventions at Bwindi Impenetrable National park Uganda (Ph.D. thesis, Wagenigen University, the Netherlands).

Archabald, K., \& Naughton-Treves, N. L. (2001). Tourism revenue-sharing around national parks in Western Uganda: Early efforts to identify and reward local communities. Environmental Conservation, 28(2), 135-149.

Ashley, C. (2000). The impacts of tourism on rural livelihoods: Namibia's experience. ODI Working Paper 128. Retrieved from https://www.odi.org/sites/odi.org.uk/files/odi-assets/publications-opinion-files/2754.pdf

Ashley, C., \& Roe, D. (1998). Enhancing community involvement in wildlife tourism: Issues and challenges. IIED Wildlife and Development Series No. 11. Retrieved from https://pubs.iied.org/pdfs/7784IIED.pdf

Ashley, C., \& Ntshona, Z. (2003). Transforming roles but not reality? Private sector and community involvement in tourism and forest development on the Wild Coast, South Africa. Sustainable Livelihoods in Southern Africa Research Paper 6. Institute of Development Studies, Brighton. Retrieved from https://pdfs.semanticscholar.org/af5f/feb8378e8700263afd8b3e1647fd787ca61a.pdf

Barrow, E., Gichohi, H., \& Infield, I. (2000). Rhetoric or reality? A review of community conservation policy and practice in East Africa. London: International Institute for Environment and Development (IIED).

Brockington, D., Duffy, R., \& Igoe, J. (2008). Nature unbound: Conservation, capitalism and the future of protected areas. London: Earthscan.

Büscher, B. (2008). Conservation, neo-liberalism and social science. Conservation Biology, 22(2), 229-231.

Coad, L., Campbell, A., Miles, L., \& Humpries, K. (2008). The costs and benefits of forest protected areas for local livelihoods: A review of the current literature. Working Paper. UNEP World Conservation Monitoring Centre (UNEP-WCMC), Cambridge. Retrieved from https://www.povertyandconservation.info/docs/20081110-Coad_et_al_2008_Working_Paper.pdf

Dabrowski, P. (2007). Tourism for conservation, conservation for tourism. Unasylva 226/227, 58. Retrieved from http://www.fao.org/tempref/docrep/fao/010/a1222e/a1222e19.pdf

Danida. (2007). Community-Based Natural Resource Management: Technical note. Ministry of Foreign Affairs of Denmark. Retrieved from http://www.netpublikationer.dk/um/8283/pdf/Technical_note_marts_2007-Community-Base.pdf

East African Community (EAC). (2006). Protocol on environment and natural resources management. Retrieved from http://repository.eac.int/bitstream/handle/11671/1638/EAC\%20PROTOCOL\%20ON\%20ENVIRONMENT\%20AND\%20N ATURAL\%20RES\%20MGMT.pdf? sequence=1\&isAllowed=y

Fabricius, C. (2007). Community-Based Natural Resource Management. Management of Agricultural, Forestry and Fisheries Enterprises, 1. Retrieved from http://www.eolss.net/sample.chapters

Fernandez-Gimenez, M. (2008). Community-Based Natural Resource Management: State of science-global perspectives. Paper presented at Planning Meeting, 16-20 June, Ulaanbaatar, Mongolia. Retrieved from http://warnercur.colostate.edu/docs/Fernandez_CBNRM_global_sun_pdf

Font, X., Cochrane, J., \& Tapper, R. (2004). Tourism for protected area financing: Understanding tourism revenues for effective management plans. Leeds: Leeds Metropolitan University.

Goodwin, H. (2002). Local community involvement in tourism around national parks: Opportunities and constraints. Current Issues in Tourism, $5(3$ \& 4), 338-360.

Hecker, J. H. (2005). Promoting environmental security and poverty alleviation in Virunga-Bwindi, Great Lakes Africa. Working Report for Institute for Environmental Security, Version 1. The Hague. Retrieved from http://www.envirosecurity.org/espa/PDF/Brochure.pdf

Hulme, D., \& Murphree, M. (2001). African wildlife and livelihoods: The promise and performance of community conservation. Oxford: James Currey Ltd.

Igoe, J. (2006). Measuring costs and benefits of conservation of local community. Journal of Ecological Anthropology, 10(1), $72-77$.

International Gorilla Conservation Programme (IGCP). (2011). The quarterly newsletter from the International Gorilla Conservation Program. Silver Standard Journey 2011. Retrieved from http://www.awf.org/economic/conservation-tourism

Kiss, A. (2004). Is community-based eco-tourism a good use of biodiversity conservation funds? Trends in Ecology and Evolution, 19(5), 232-237. 
Laudati, A. (2010). Ecotourism: The modern predator? Implications of Gorilla tourism on local livelihoods in Bwindi Impenetrable National Park, Uganda. Environment and Planning D: Society and Space, 28(4), 726-743.

Muramira, T. E., \& Sikoyo, G. M. (2001). Wildlife enterprises: The national frame work in Uganda. Ministry of Tourism Wildlife and Antiquities. Kampala, Uganda.

Mburu, J. (2003). Wildlife conservation and management in Kenya: Towards a co-management approach. FEEM Working Papers No. 47.04. Retrieved from https://ssrn.com/abstract $=524543$

Nthiga, R. W. (2014). Governance of tourism conservation partnerships: Lessons from Kenya (Ph.D. thesis, Wagenigen University, Wagenigen NL).

NEABS. (2005). The national environment access and benefit sharing regulations. No. 30 of 2005. Government of Uganda.

Nyakaana J. B., \& Ahebwa, M. W. (2011). Governance of community-based tourism in Uganda: An analysis of the Kibale Association for Rural and Environmental Development (KAFRED). In R. van der Duim, D. Meyer, J. Saarinen, and K. Zeumer (Eds.), New alliances for tourism conservation and development in Eastern and Southern Africa. Delft, Netherlands: Eburon Publishers.

Ross, S., \& Wall, G. (1999). Ecotourism: Towards congruence between theory and practice. Tourism Management, 20(1), $123-132$.

Saarinen, J., Becker, F., Wilson, D., \& Manwa, H. (2009). Sustainable tourism in Southern Africa: Communities, and natural resources in transition. Bristol: Channel View Publication.

Sachedina, H., Igoe, J., \& Brockington, D. (2010). The spectacular growth of a conservation NGO and the paradoxes of neo-liberal conservation. Current Conservation, 3(3), 24-27.

Saito, F. (2007). Local council commons management in Uganda: A theoretical reassessment. Discussion Paper No. 153. Graduate School of International Development, Nagoya University, Japan.

Sandbrook, C. G. (2006). Tourism, conservation and livelihoods: The impacts of gorilla tracking at Bwindi Impenetrable National Park, Uganda (Ph.D. thesis, University College London, University of London, London).

Southgate, C. (2006). Ecotourism in Kenya: The vulnerability of communities. Journal of Ecotourism, 5(1 \& 2), 80-96.

Spenceley, A. (2003). Tourism, local livelihoods and the private sector in South Africa: Case studies on the growing role of the private sector in natural resources management. Sustainable Livelihoods in Southern Africa Research Paper 8, Institute of Development Studies, Brighton.

Tao, T. C. H., \& Wall, G. (2009). Tourism as a sustainable livelihood strategy. Tourism Management, 30(1), 90-98.

Uganda. (1995). Constitution of the Republic of Uganda. Retrieved from https://washington.mofa.go.ug/data-smenu-71-The-Constitution-of-Uganda.html

Uganda. (2000). The Uganda Wildlife Act, Cap 200. Ministry of Tourism Wildlife and Antiquities. Retrieved from https://www.unodc.org/res/cld/document/the-uganda-wildlife-act_html/The_Uganda_Wildlife_Act.pdf

Uganda. (2008). Building a foundation for sustainable wildlife trade in Uganda: A review of the national wildlife trade policies in support of the convention on international trade in endangered species of Fauna and Flora (CITES). National Environment Management Authority (NEMA), Ministry of Water and Environment.

Uganda. (2014). Uganda wildlife policy. Ministry of Tourism, Trade and Industry. Retrieved from http://extwprlegs1.fao.org/docs/pdf/uga174672.pdf

UN WTO. (2008). Indicators of sustainable development for tourism destinations: A guide book. Madrid: UN WTO.

Varghese, G. (2008). Public-private partnerships in South African National Parks: The rationale, benefits and lessons learned. In A. Spenceley (Ed.), Responsible tourism; critical issues for conservation and development (pp. 69-84). London: Earthscan.

Wells, M., Brandon, K., \& Hannah, L. (1992). People and parks: Linking protected area management with local countries case-Studies of integrated conservation and development projects world congress on national parks and protected areas. Washington, D.C.: IBRD/World Bank.

Wells, M., \& Brandton, K. (1993). The principles and practice of buffer zones and local participation in biodiversity conservation. Ambio, 22(2/3), 157-162.

Wells, M., \& McShane, T. O. (2004). Integrated protected management with local needs aspirations needs and aspirations. Ambio, 33(8), 513-519. 